\title{
Medicinal Plants and Their Conservation in China with Reference to the Chinese Himalayan Region
}

\author{
Pei Shengji, Huai Huyin, and Yang Lixin
}

\begin{abstract}
The use of herbal medicine in China has a long history. Since ancient times, plants have been the main source of medicines for people's healthcare all over China. Today, medicinal plants are widely used in different medical systems including Traditional Chinese Medicine (TCM) and Tibetan Medicine (TM) for health care and functional food in China, and as supplies of natural products for industrial manufacturing for the international market. In the last half-century, great progress has been made in science and technology and there has been rapid social and economic development. The impact of this rapid development and population pressures on medicinal plants from wild habitats increases day by day. The modernization policy of traditional medicine in China is seen as a challenge to maintaining traditional medical systems. The Chinese Himalayan Region covers five provinces (Tibet, Qinghai, Gansu, Sichuan, and Yunnan) in west China, with a land area of 2 million $\mathrm{km}^{2}$, including the Qinghai-Tibetan Plateau in the west and the Hengduan Mountains in the southwest. In this paper, we discuss the rich diversity of medicinal plants of China and the Chinese Himalayan Region; the diversity of medicinal plant utilization of China; threatened medicinal plants and threats to medicinal plants; the conservation status of medicinal plants in China; and proposed Important Plant Areas for medical plants in the Chinese Himalayan Region.
\end{abstract}

\section{Keywords}

Medicinal plants, biodiversity, traditional medicine, Chinese Himalayan Region, conservation, plant reserves (Important Plant Areas)

\section{Background}

The use of herbal medicine in China represents a long history of human interaction with the environment. In China, traditional medicine systems are diverse and still play an important role in human health care presently. For example, Traditional Chinese Medicine (TCM) is one of the oldest medical systems in the world. Written accounts testify to the usefulness of Chinese herbs for medicinal purposes. The history of TCM can be traced back to 3000 BC. Shen Nong's Classic of Materia Medica (Shen Nong Ben Cao Jing 神农本草经) is suggested to be one of the earliest sources of folk knowledge 
on the use of medicinal plants; this compendium mentions 365 plants, animals, and minerals that have medicinal uses or properties from the period of Shen Nong. ${ }^{1}$ Recent studies on Tibetan medicine have shown that some of the earliest literature on Tibetan medicine was produced in the eighth century AD. ${ }^{2}$

From ancient literature to modern scientific records of traditional medicinal knowledge, there is evidence that plants represent the main medicinal source for people's health care in China. For instance, the updated inventory of medicinal plants used in Traditional Chinese Medicine (TCM) includes 11,146 species, of which 492 species are cultivated and the remaining 10,654 species are wild plants. ${ }^{3}$ The updated Tibetan Medicine (TM) inventory consists of 2,685 plants, 159 animals, and 80 natural minerals. ${ }^{4}$ According to the World Health Organization (WHO), more than $80 \%$ of the world's population relies on traditional herbal medicine to meet their primary healthy care needs. ${ }^{5}$ These valuable herbal medicine traditions found in many so-called 'developing' countries (including China) have always been considered important components of the world's cultural heritage. Today, traditional medicines in China are as important as antibiotic and chemical medicines; both are accepted in public and private health care systems and integrated with each other in clinical practices.

However, over the last half-century, environmental and cultural changes, and economic transitions from subsistence to market-based in China have created a serious impact on all aspects of traditional medical systems by affecting traditional medicine's resource base and environment. Over-harvesting of medicinal plant and animal species has resulted in resource degradation, loss of biodiversity, and the loss of indigenous medical knowledge and traditions. This has led to something of a breakdown of traditional medical systems in the country. Moreover, the accelerated exploitation of herbal medicine for the creation and development of new drugs that supply modern markets with allopathic treatments may eventually lead to the replacement of traditional medicine.

\footnotetext{
${ }^{1}$ Pei 1987. Editors' note: Shen Nong, literally the 'Divine Farmer', is credited with having introduced agriculture to China close to 5,000 years ago. The book Shen Nong Herbal is attributed to Shen Nong but was most likely written during the Han Dynasty (206 BC-220 AD).

2 Yang 1988.

3 SEPA 1998; Pei 2002; Hamilton 2004.

${ }^{4}$ Zheng 2003.

${ }^{5}$ Inglis 1994.
} 


\section{Medicinal plants in the Chinese Himalayan region}

\section{Geographical area, biodiversity and people}

The Chinese Himalayan Region (CHR) covers a huge area and includes most of the Qinghai-Tibet Plateau and the Hengduan Mountains, adjacent to the neighbouring countries of Pakistan, India, Nepal, and Bhutan in the west, Myanmar in the southwest, and the Karakoram in the north. The area extends toward the eastern edge of the Hengduan Mountains, covering the QinghaiTibet Plateau, west Sichuan and south Gansu and large parts of Yunnan in the South. It spans three climate zones: tropical, temperate, and frigid zones, with a total area over 2 million square kilometres, making up one-fifth of the total landmass of China (Fig. 1). ${ }^{6}$ Most of the Chinese Himalayan Region is situated over 3000 metres above sea level; ecological environments are extremely diverse and fragile. Alpine vegetation and evergreen mountain forests are dominant in the region, which provides not only ecological services to the stability of mountain ecosystems but is also of economic importance to the human population. One aspect of these functions is providing natural plants for health care of local people. The values of medicinal plants are closely linked with indigenous/traditional medical systems and, concomitantly, the economic livelihood of local people in particular mountain communities in the Chinese Himalayan Region.

Geographically, the Chinese Himalayan Region is located in four provinces (Qinghai, Gansu, Sichuan, and Yunnan) and one autonomous region (Tibetan Autonomous Region, Tibet, or Xizang) of western China, making-up onefifth of the total landmass of China. ${ }^{7}$ The general topography of the region is higher in the west, forming the major terraces: the Qinghai-Tibet Plateau, the longest and highest plateau in the world, and the Hengduan Mountains, which includes one of the greatest gorges in the world. Different combinations of temperature and precipitation and the complex topography make for an extremely varied climate: the southern and eastern parts of this region have dense precipitation and are humid, whereas the north-western parts, deep in the Plateau and far from the Pacific Ocean, are extremely dry. Between the two there is a wide semi-arid intermediate zone. The diverse geographic, topographic, and climatic conditions provide the basis for the region to be one of the most biologically diverse areas of China and the world (see Table 1).

\footnotetext{
${ }^{6}$ Hong and Li 1995.

${ }^{7}$ For the sake of simplicity, we will refer to all five of these administrative units as 'provinces' throughout this paper, even though the Tibetan Autonomous Region has a different administrative classification.
} 


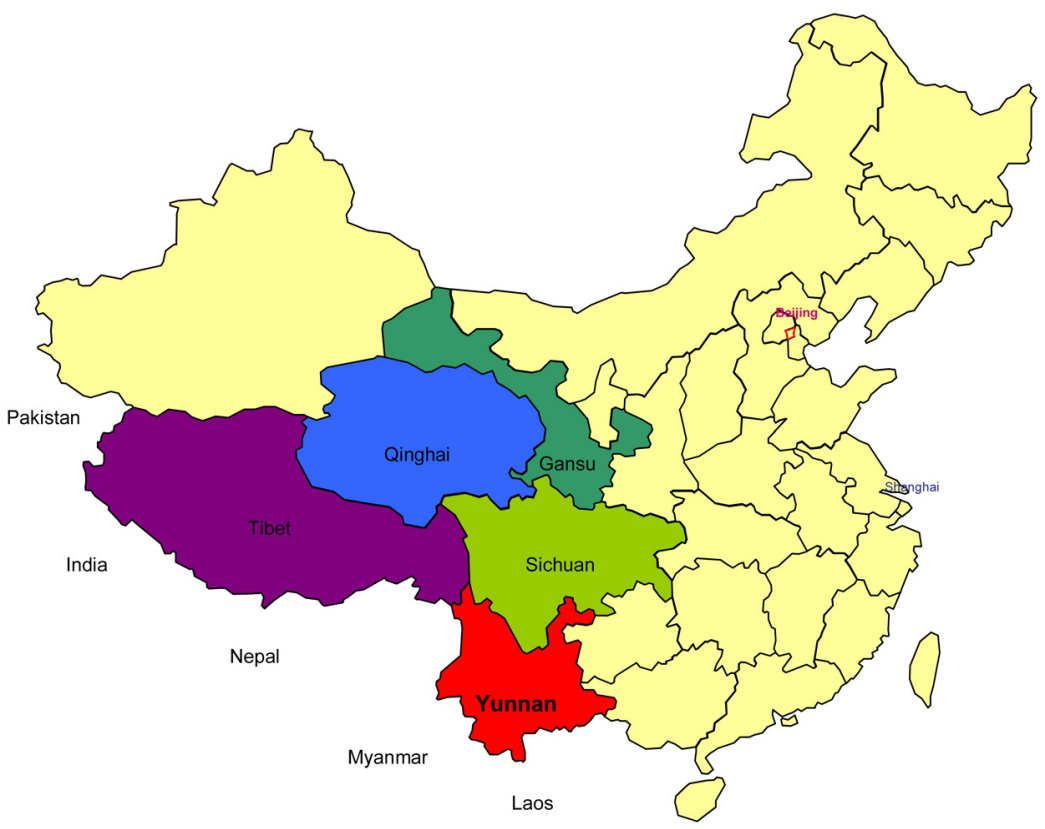

Fig. 1. Location of Chinese Himalayan regions

Table 1. Biological diversity of the Chinese Himalayan provinces ${ }^{8}$

\begin{tabular}{lccc}
\hline Province & No. of higher plants & No. of vertebrates & No. of useful plants \\
\hline Yunnan & 17,000 & 1,737 & 12,000 \\
Sichuan & 9,628 & 1,239 & 8,000 \\
Xizang & 5,476 & 798 & 2,500 \\
Qinghai & 2,500 & 420 & 2,000 \\
Gansu & 3,000 & 922 & 2,000 \\
\hline
\end{tabular}

The population of the five provinces of the Chinese Himalayan region is about 120 million of which $30 \%$ are ethnic minorities belonging to 30 different cultural groups, including Tibetan, Yi, Hui, Naxi, Bai, Qiang, Lisu, Lahu, Jingpo, Yugar, and Donxiang. Overall, these ethnic groups display considerable cultural and economic diversity. They vary from hill people who practice forestry and terraced agriculture to mountain grasslands and high plateaudwelling groups whose primary mode of subsistence is animal husbandry, dominated by alpine pasture grazing.

\footnotetext{
${ }^{8}$ Source: Provincial floras. Lists of plant and animals of concerned provinces 1980-2003.
} 
Like other parts of the Himalayan region, the area is landlocked and mountainous. Its transportation, communication, and infrastructure were largely underdeveloped until the 1980s. Economic development in the region is generally based on subsistence agriculture, forestry, and animal husbandry, including various non-timber forest products (NTFP) including cash crops, medicinal plants, cattle, and mining products. Compared with other parts of China, the Chinese Himalayan region is less economically and infrastructurally developed. However, over the last two decades, rapid economic development in China overall has strongly impacted the Chinese Himalayan region. On the one hand, rapid mountain infrastructure and tourism development have brought about economic growth and improvement of livelihoods of mountain people. On the other hand, population growth, land-use change, deforestation, overgrazing, destructive mining, and over-harvesting of wild plants including medicinal plants have resulted in serious impacts on ecosystems and environments. With loss of biodiversity and decline of wild medicinal plant resources, and with continuing population growth and economic development in China, the conflict over the use and conservation of biodiversity resource has become more intense. The future of the Chinese Himalayan environment and biodiversity will see more critical challenges than before.

\section{Important areas for medicinal plants}

The complex environment and varied ecosystem types of the Chinese Himalayan lead to a very high level of plant diversity as well as high cultural diversity. Different ethnic cultures have established diverse traditional medical systems in this region. The habitat for medicinal plants in the region varies from lowland foothill to alpine high Himalayas consisting of following major ecosystem types: ${ }^{9}$

- Tropical rain forest ecosystem and monsoon rain forest ecosystems in foothills and lowland valleys, comprising evergreen monsoon rain forest, semi-evergreen monsoon rain forest, and deciduous monsoon rain forests (below 1,000m)

- Evergreen broad-leaved forest ecosystems at middle elevations (1,0002,500m)

- Sclerophyllous evergreen, broad-leaved forest and sclero-microphyllous forest, and Mediterranean-like marquis vegetation ecosystems in Hengduan mountains (dry and hot valleys in the Hengduan Mountains, $1,200-2,500 \mathrm{~m})$

\footnotetext{
9 Wu 1979; Hong and Li 1995; Pei 1998.
} 
- Mixed conifer and broad-leaved forest ecosystems in alpine mountain ranges $(2,200-3,000 \mathrm{~m})$

- Evergreen conifer forest ecosystems, widely distributed (1,800-3,500m)

- Deciduous conifer forest ecosystems (Larix spp.) in alpine mountains $(2,500-3,000 \mathrm{~m})$

- Evergreen broad-leaved bush ecosystems; Evergreen coriaceous bush ecosystems, evergreen conifer bush ecosystems, and deciduous broad-leaved bush ecosystems widely distributed in Hengduan mountains and alpine and high Himalayas $(1,200-3,800 \mathrm{~m})$

- Sub-alpine scrub, meadow ecosystems, and steppe ecosystems in alpine and high Himalayas $(3,000-4,200 \mathrm{~m})$

- Alpine desert, semi-desert, mountain alpine deserts in high cold Himalayas $(4,000-4,800 \mathrm{~m})$

- Alpine shrub lands and Meadows in alpine and high Himalayas $(3,800$ $45,00 \mathrm{~m})$

- Super-alpine glacier snow ecosystems in alpine and high Himalayas $(3,800-4,500 \mathrm{~m})$

- Aquatic ecosystems and plateau wetlands distributed over the Chinese Himalayan region (freshwater lakes, swamps, river-banks from 1,200 to $6,000 \mathrm{~m})$

- Bamboo forests in the Hengduan Mountains (800-3,200m)

- Farming ecosystems located in areas below 4,500m

Botanically, the Chinese Himalaya covers two particularly notable centres of plant diversity and endemism: the Gaoligong Mountains-Nu Jiang River and Biluo Snow Mountains in the South Hengduan Mountains, and the Xishuangbanna region in Southern Yunnan. ${ }^{10}$ Both centres have been recognized by the Chinese government and conservation agencies; both have recognized these regions as critical areas for biodiversity conservation in China. Traditional medical systems in the Chinese Himalayan Region are diverse and well maintained. There are three major traditional medical systems in the Chinese Himalayas: Traditional Chinese Medicine (TCM), Tibetan Medicine (TM) and Traditional Dai Medicine (TDM). Other traditional medicines, such as Yi Medicine, Naxi Medicine, Qiang Medicine, Lahu Medicine and other ethnic minority medicines, are also practised locally in the region. The formation of TM is closely correlated with the biophysical environment traits and biodiversity of the Qinghai-Tibet Plateau; many medicinal plants in the Chinese Himalayan Region are used by TM and TCM as well as other traditional

\footnotetext{
${ }^{10}$ Hong and Li 1995.
} 
Table 2. Medicinal plants in China and the Chinese Himalayan region ${ }^{11}$

(1) Medicinal Plants

\begin{tabular}{lcccccc}
\hline & Algae & Fungi & Lichens & Bryophytes & Ferns & Seed plants \\
China & 115 & 292 & 52 & 43 & 456 & 10,188 \\
CHR & - & 50 & 6 & 5 & 118 & $1942 \& 144$ var. \\
\hline
\end{tabular}

(2) Medical plants in Chinese Himalaya Region: No. of species identified by Province

\begin{tabular}{lcccc}
\hline Yunnan & Sichuan & Xizang & Qinghai & Gansu \\
4,758 & 3,962 & 1,460 & 1,461 & 1,270 \\
\hline
\end{tabular}

Table 3. Species number of endangered plants in China ${ }^{12}$

\begin{tabular}{lccr}
\hline Group & No. of species & No. of Endangered spp. & Ratio \% \\
\hline Bryophytes & 2,200 & 28 & 1.3 \\
Fern & 2,600 & 80 & 3.1 \\
Gymnospermae & 200 & 75 & 37.5 \\
Angiospermae & 25,000 & 826 & 3.3 \\
Total & 30,000 & 1009 & 3.4 \\
\hline
\end{tabular}

medicines in China. Therefore, the Chinese Himalayan Region is the most important sourcing area for traditional medicines in China. The numbers of medicinal plants found in China and in Chinese Himalayas are summarized in Table 2.

\section{Broad threats to medicinal plants}

Medicinal plants in China are under pressure and many wild species are threatened. Table 3 shows the general situation of endangered plant species in China.

According to statistics (Table 3) the endangered (EN) plant species of China number 1,009 species and the Near Threatened (NT) species of plants was estimated at 3000-4000 species. EN plus NT plant species in China thus

11 Sources: Chinese Corporation of Traditional and Herbal Medicine 1995; SEPA 1998;

Zheng 2003. Additionally, provincial floras, and lists of plants of concerned provinces of China (1980-2003) were also consulted.

12 Source: Yuan et al. 2003. 
comprise about 4000-5000 species, and total EN and NT medicinal plant species has been estimated at 1500-2000 species. ${ }^{13}$

The Red Book of China (Institute of Botany 1992) listed as endangered some 46 medicinal species, e.g. Panax ginseng, Panax gingiberensis, Panax pseudoginseng, Dendrobicum candidum, Aconitum nagarum var. heterotrichum, Coptis teeta, Cephalotaxus mannii etc. Rare species include 38 species, such as Taxus wallichiana, Eucommia ulmoides, Psammosilene tunicoides, Magnolia rostrata, $M$. wilsonii, Kingdonia uniflora, Sinopodophyllum emodii, Depentodon sinicus, and Davidia involucrate. On 4 August 1999 the state council issued 'National Priority Protection List of Wild Plants' listing 393 species of wild plants, 101 species of which are medicinal plants. The updated numbers of protected medicinal

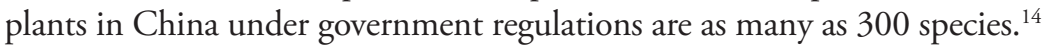

Overall factors that impact the biodiversity and mountain environments are both internal and external. Factors that significantly cause a threat to medicinal plants in China are identified as follows:

\section{Deforestation and habitat alteration}

Deforestation and land use change are seen as the main factor to cause habitat loss for medicinal plants in Chinese Himalayas. For instance, during 1960s-1990s, logging operations expanded into the Hengduan Mountains, seriously impacting alpine coniferous forests and evergreen broadleaved forests in northwest Yunnan and west Sichuan. Population growth in the region has resulted in expansion of shifting agriculture in foothill and low altitude mountain areas of the Chinese Himalaya during 1960s-1980s. The loss of forest vegetation has been one of the major causes of threats to biodiversity, as there are about 1000 to 1500 species of medicinal plants distributed only in the forest ecosystems, e.g. Taxus yunnanensis, Dendrobium spp., Paris polyphylla var. yunnanensis etc. Table 4 indicates the average rates of deforestation and reforestation in five countries of the Himalayan Region during the 1970s-1980s, in which China and Pakistan are at the highest deforestation rate among the five countries.

\section{Overharvesting of wild medicinal plants}

The total wild medicinal plant resources of China are 8.5 million tons and the total annual production of cultivated medicinal plants are over 0.3 million tons. ${ }^{15}$ However, the common harvested medicinal plants for traditional medicines in China are less than 1,000 species, of which 500-600 species are from

13 Yuan et al. 2003.

14 Yuan et al. 2003.

15 Wang et al. 2002. 
Table 4. Estimated average rates of deforestation and reforestation in the Himalayan region during the 1970 s and $1980 s^{16}$

\begin{tabular}{|c|c|c|c|c|c|c|c|}
\hline \multirow{3}{*}{$\begin{array}{c}\text { Countries } \\
\text { (1) }\end{array}$} & \multirow{4}{*}{$\begin{array}{c}\text { Total } \\
\text { Forest } \\
\text { area } \\
\text { O00 ha } \\
(2)\end{array}$} & \multicolumn{2}{|c|}{$\begin{array}{c}\text { Annual } \\
\text { Deforestation } \\
\\
000 \text { ha } \% \text { of }(2)\end{array}$} & \multicolumn{4}{|c|}{ Annual Reforestation } \\
\hline & & $\begin{array}{l}\text { Area } \\
\text { O00ha }\end{array}$ & $\begin{array}{c}\% \text { of } \\
(2)\end{array}$ & \multicolumn{2}{|c|}{$\begin{array}{c}\text { Gross area } \\
\text { planted } \\
000 \text { ha } \% \text { of }(3)\end{array}$} & \multicolumn{2}{|c|}{$\begin{array}{c}\text { Net area }(50 \% \\
\text { survival rate } \\
\text { '000) ha } \% \text { of }(3)\end{array}$} \\
\hline & & \multicolumn{2}{|c|}{ (3) } & \multicolumn{2}{|c|}{ (4) } & `000 ha & $\begin{array}{l}\% \text { of } \\
\text { (3) }\end{array}$ \\
\hline & & & & & & \multicolumn{2}{|c|}{ (5) } \\
\hline Pakistan & 3.077 & 30 & 1.0 & 7 & 23 & 3.5 & 12 \\
\hline India & 21.648 & 50 & 0.2 & 37 & 74 & 18.5 & 37 \\
\hline Nepal & 5.424 & 44 & 0.8 & 8 & 18 & 4 & 9 \\
\hline Bhutan & 2.765 & 2 & 0.1 & 1 & 50 & 0.5 & 25 \\
\hline China & 36.240 & 362 & 1.0 & 270 & 75 & 135 & 37 \\
\hline
\end{tabular}

wild resources. There is no exact figure to show how much of them are from the Chinese Himalayas; an estimation suggests that the common wild harvested medicinal plants are 200-300 species and amongst 150-200 species are collected from different wild habitats in Chinese Himalaya region. A list of the top 100 species of medicinal plants in the Chinese Himalayan Region, compiled by the authors, is attached as an appendix to this paper.

In recent years, due to increased domestic market demands, resulting from rapid population growth and improvement of health case system, over-harvesting of wild plants for medicine has become a common problem in the Chinese Himalayan provinces. This affects in particular the high value plants, e.g. Cordyceps sinensis, Glycyrrhiza uralensis, Epimedium brevicornum, Ephedra sinica, Gastrodia alata, Gentiana macrophylla, and G. scabra, Fritillaria spp., Dendrobium spp., Bergeria purpurascens, Eucommia ulmoides, Taxus chinensis and T. wallichiana, Erigeron breviscapus, Cistanche salsa, Aquilaria sinensis, Paris polyphylla var. yunnanensis, Saussurea lappa, Psammosilene tunicoides, Sinopodophyllum emodi, Dracaena cochinchinensis, Rauwolfia yunnanensis, Homalomena occulta, Rheum officinale, Salvia miltiorrhiza, Dioscorea deltoidea

\footnotetext{
16 Source: ICIMOD, 1994.
} 
and D. nipponica, D. zingiberensis, Coptis teeta and C. omeiensis, Picrorhiza scorophulariiflora, Stephania epigaea and S. yunnanensis, Panax ginseng and $P$. pseudoginseng etc. Some of these species have become almost extinct in wild habitats.

Degradation of pastures as a result of overgrazing and gold mining

Pasture, meadow steppe, and scrub ecosystems are important habitats for medicinal plants in the Chinese Himalayan Region. Due to overgrazing, vegetation degradation occurs in many areas of this region. In the Qinghai-Tibet Plateau area over the last forty years the number of cattle has doubled. ${ }^{17}$ This has led to overgrazing in the pastures of the region, and has further resulted in degradation of pasturelands and declining of biodiversity including medicinal plants. For instance in the Zoige Pastures of northwest Sichuan, the desertification area has been expanded to $1053 \mathrm{~km}^{2}$ in 2007 from $253 \mathrm{~km}^{2}$ in $1999 .^{18}$ In the 1980 s, with the improvement of transportation in high cold pastures of the Plateau and its conjunction with a high cold desert area, the Hoh Xil area, each year thousands of rural people from outside the region rushed in for gold mining, which resulted in destruction of the natural ecosystem and left thousands of mining caves on the pastures and cold desert. Natural vegetation was covered by excavated mud, stone and sand. ${ }^{19}$ Large areas of natural plant communities, e.g. Pinus geradiana, Picea smithiana, Myricaria elegans, Sophora moorcroftiana and Ceratoides spp. were destructively harvested for construction materials and fuel for gold rush workers. ${ }^{20}$

According to the report of SEPA, in the Qinghai-Tibet plateau area, there are at least 35 species of plants that are endangered and threatened. These include: Gymnogrammitis dareiformis, Cupressus gigantea, Ilex integra, Dysosma tsaynansis, Typhonium austro-tibeticum, Solmslanbachia eurycarpa, Indofeviliea khasiana, Stracheya tibetica, Mandragora chinghaiensis. ${ }^{21}$

\section{Socio-economic factors causing decline of cultivated medicinal plant production} Traditionally, mountain communities of the Chinese Himalayan Region engaged in mountain farming, forestry, and animal husbandry. Collecting medicinal plants from various mountain ecosystems has been an important part of their income. In addition, cultivation of medicinal plants primarily to

\footnotetext{
7 SEPA 1998.

8 Zhao 2008.

9 Duan 2003; Huang 2006.

SEPA 1998.

1 SEPA 1998.
} 
supply the TCM market materials in China and the international market has been equally important. The sustainability of wild harvesting and the cultivation of medicinal plants have been affected by changes in the land tenure system and resources rights. Over the last half-century, in particular during the 1960 s to 1980 s, socio-economic policy changes have impacted the stability of land tenure and common resources, including forests and pasture management. This has resulted in declining medicinal plant production from cultivated land, and uncontrolled wild harvesting from natural habitats. Some examples are as follows: declining cultivation areas for Limon grass (Cymbopogon citratus), Cinnamomum cassia, Chinese cardamon (Amomum villosum), Eucommia ulmoides, Panax ginseng, Panax notogenseng, Dioscorea spp., Poria cocos, Ligusticum chuanxiong etc., and uncontrolled wild harvesting of Ephedra spp., Dendrobium spp., Dracaena cochinchinensis, Dysosma spp., Coptis teeta, Apocynum spp., Aquilaria sinensis, Cordyceps sinensis, Saussarea spp. etc. Unstable market prices for medicinal plants further affect the sustainable supply of plants at local levels. In the transition from a centralized economy to a market-oriented economy in China, rural communities in mountain areas are in a weak position. Benefit sharing is only a topic for discussion at academic conferences. And again, traditional cultural beliefs of Chinese people about rare and wild medicinal plants play a significant role in consumers' preference: 'the wild is the best' is the rule for such species as Cordyceps sinensis, ginseng (Panax japonica var. major), Gastrodia elata and Coptis teeta. Wild-sourced plants of these species are much higher in price than cultivated ones. This eventually results in extinction of those medicine plants in natural habitats.

\section{Conservation measures for medicinal plants}

Since the 1980s, the government of China has begun to pay attention to the conservation of medicinal plants. The first step was the creation of legislation and endorsement of the 'Forest Law', 'Environment Protection Law', and 'Regulations on Protection and Management of Wild Animals'. On 30 October 1987, the State Council promulgated the 'Regulations on Protection and Management of Wild Medicinal Materials', which established principles for protection and regulating wild collecting and cultivation of medicinal plants.

Priority protected species in China are classified into three categories: (1): wild species that are near extinction and rare, precious medicinal species, which are prohibited for collecting from the wild; (2): important medicinal species whose distribution area is shrinking and whose resource levels are 
decreasing, for which collecting and trading are controlled by special licenses issued by government; and (3) commonly used major medicinal species whose resources are declining; collecting and trading of those species are also controlled by special license issued by the government. ${ }^{22}$ At the same time, the government made a list of priority-protected medicinal species. These include animals (18 spp.) and plants (58 spp.), including 13 spp. such as Glycyrrhiza uralensis, Coptis spp., Panax ginseng, Eucommia ulmoides, Magnolia officinalis, Phellodendron amurense, Dracaena cochinchinensis, etc. Protected species include 45 spp. plants, such as: Fritillaria cirrhosa, F. pallidiflora, F. przewalskii, F. unibracteata, F. walujewii, Acanthopanax senticosus, Scutellaria baicalensis, Gentiana macrophylla; G. scabra, G. triflora, Asparagus cochinchinensis, Picrorhiza scrophulariiflora, Asarum siebodii, Terminalia chebula, T. chebula var. tomentosa, Evodia trichotoma, Dendrobium officinale, D. candidum, D. fimbrifiatum, D. nobile, D. loddigesii, Ferula asafoetida, Cistancha salsa, Notopterygium incisum, etc.

The Red Book of China (Institute of Botany 1992) includes 398 endangered plants species, of which 168 are medicinal plants. Endangered account for 46 spp., while rare and vulnerable are listed at 38 and 46 spp., respectively. The State Forestry Administration (SFA) enacted a list of 'National Priority for Protection of Wild Plants' including 393 spp. Of these, medicinal plants represent 101 species, including 10 in the first category and 91 in the second category. In 1995 the State Environment Protection Agency launched 'China National Action Plan for Biodiversity Conservation', in which 151 species of plants are emphasized for urgent protection. Of these, 19 species are medicinal plants. These include Panax ginseng, Hydnocarpas hainanensis, Dracaena cochinchinesis, Ammopitanthus nanus and A. mongolicus.

Protected Area systems play an important role in the conservation of medicinal plants and habitats in China. By 2004, China established 2194 Protected Areas (PAs), occupying an area of $14,822.6$ ha and making up $14.8 \%$ of total territorial landmass of China. More than fifty percent of the medicinal plant species are found in various Protected Areas. Ex-situ conservation of plants in China is mainly within botanical gardens. As of 2005 there were 220 botanical gardens established in China. Among them about 10 gardens are specialized medicinal plant gardens. In 2004, the Southwest China Wild Plants Germplasm Bank was established by Chinese Academy of Science at the Kunming Institute of Botany. Germplasm conservation of medicinal plants was identified as an important measure of conservation biodiversity.

22 Zhou, et al., 2007. 


\section{Proposed important medicinal plant areas in the Chinese Himalayan region}

The Chinese Himalayan region is the most important sourcing area for medicinal plants in China. Based on the plant diversity and species richness for medicinal plants, incorporated with the identified critical regions for China biodiversity conservation, and supply of medicinal plants to TCM and Tibetan medicine, the authors propose the following six areas in the Chinese Himalayan Region should be recognized as Important Plant Areas (IPAs) for Medicinal Plants (Fig. 2):

A Northwest Yunnan area in the South Hengduan Mountains. Land area of northwest Yunnan is $89,200 \mathrm{~km}^{2}$, altitude varies from $1200-6740 \mathrm{~m}$; number of medicinal plants about 2000-2500 spp. distributed in the area.

B West Sichuan area located in west Sichuan covers about 100,000 km² land in the Mingshan mountain and northern part of the Hengduan mountains; altitude varies from 1000-5500m; number of medicinal plants estimated about 1000-1200 spp. distributed in alpine forests, pastures and cultivated lands.

C Southwest Sichuan area located in the southeast Hengduan Mountains with a land area of $40,000 \mathrm{~km}^{2}$; altitude varies from 700 to $7,557 \mathrm{~m}$; total medicinal plants about 800-1000 spp. distributed in the hot and dry valleys, alpine forests and pastures.

D South Gansu area located in the southern part of Gansu Province, with a land area of $25,000 \mathrm{~km}^{2}$, covered by high pastures and alpine forests; altitude varies from 2500 to $4500 \mathrm{~m}$; total number of medicinal plants about 1,200 spp.; the area is considered as an important medicinal plant supply area for Tibetan medicine.

E West-Qinghai and North-Tibetan area, a vast high, cold pasture and desert area, occupying about $150,000 \mathrm{~km}^{2}$ land area at 4,200 to $5,500 \mathrm{~m}$ above sea level; number of medicinal plants about 500-600 spp., many are endemic and rare species; the area is also the origin of three major rivers (Yangtze, Yellow, and Mekong).

F South-Tibetan area, in south and southeast parts of TAR; land area about $300,000 \mathrm{~km}^{2}$; altitude varies from 2800 to $5,500 \mathrm{~m}$; number of medicinal plants about 600-800 spp.

The plants listed in Table 5 are only part of threatened medicinal plants in northwest Yunnan, which can be used as priority conservation species in this region. 


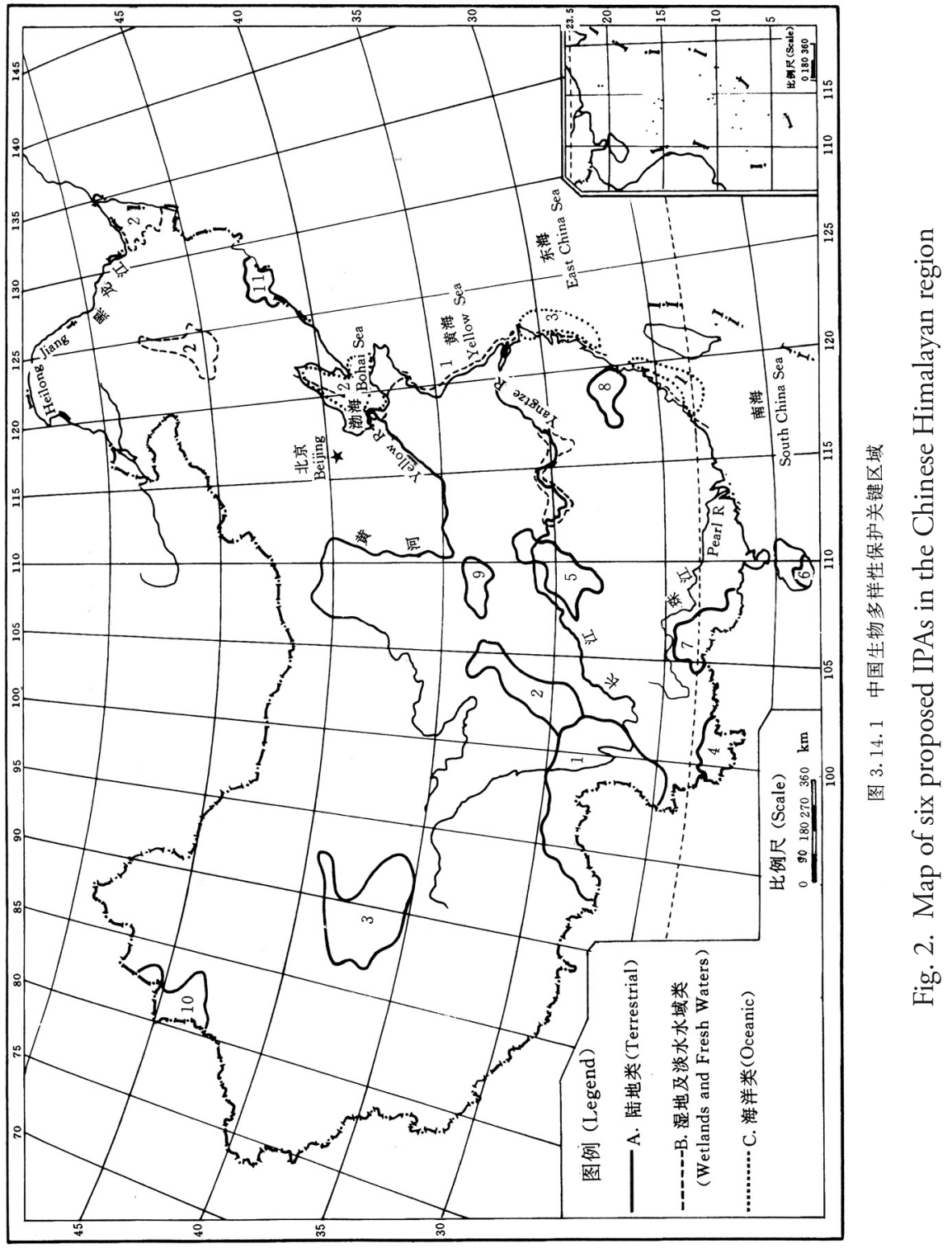


Table 5. Twenty threatened medicinal plants $(2,500-3,200 \mathrm{~m})$ in Northwest Yunnan $^{23}$

\begin{tabular}{|c|c|c|c|c|}
\hline Botanical Name & $\begin{array}{l}\text { Protection } \\
\text { Category }\end{array}$ & Endemism & Habitat & Source \\
\hline $\begin{array}{l}\text { Aconitum } \\
\text { brachypodum Diels }\end{array}$ & III VU & $\sqrt{ }$ & $\begin{array}{l}\text { Alt. } 2500-3000 \mathrm{~m} \text {, Warm } \\
\text { Evergreen Broad-leaved } \\
\text { Forest, Needle-leaved and } \\
\text { Broad-leaved Forest }\end{array}$ & (1), (3) \\
\hline $\begin{array}{l}\text { Aconitum contortum } \\
\text { Finet et Gagnep. }\end{array}$ & $\begin{array}{l}\text { II } \\
\text { EN }\end{array}$ & $\sqrt{ }$ & Bush land & (2) \\
\hline $\begin{array}{l}\text { Anisodus tanguticus } \\
\text { (Maxim.) Pascher }\end{array}$ & II EN & $\sqrt{ }$ & $\begin{array}{l}\text { Alt. } 2500-3000 \mathrm{~m} \text {, Warm } \\
\text { Evergreen Broad-leaved } \\
\text { Forest, Needle-leaved and } \\
\text { Broad-leaved Forest }\end{array}$ & $(4)$ \\
\hline Coptis teeta Wall. & I VU & - & Grass Land & $(1),(2)$ \\
\hline $\begin{array}{l}\text { Cordyceps sinensis } \\
\text { (Berk.) Sacc. }\end{array}$ & II EN & $\sqrt{ }$ & $\begin{array}{l}\text { Alpine Meadow and Alpine } \\
\text { Bush, Alt. } 3000-6000 \mathrm{~m}\end{array}$ & $(1),(2)$ \\
\hline $\begin{array}{l}\text { Fagopyrum dibotrys } \\
\text { (D. Don) Hara }\end{array}$ & $\begin{array}{l}\text { II } \\
\text { VU }\end{array}$ & $\sqrt{ }$ & Bush land \& Pastures & $(1),(2)$ \\
\hline $\begin{array}{l}\text { Gentiana macrophylla } \\
\text { Pall. }\end{array}$ & III VU & $\sqrt{ }$ & Alpine Meadow & $(4)$ \\
\hline Gastrodia elata Bl. & III VU & $\sqrt{ }$ & Broad-leaved Forest & $(1),(2)$ \\
\hline $\begin{array}{l}\text { Meconopsis punicea } \\
\text { Maxim. }\end{array}$ & II EN & $\sqrt{ }$ & Alpine Meadow & $(4)$ \\
\hline $\begin{array}{l}\text { Notopterygium incisum } \\
\text { Tign. }\end{array}$ & III VU & $\sqrt{ }$ & Grass land & $(4)$ \\
\hline $\begin{array}{l}\text { Paeonia devayi Franch. } \\
\text { Var. lutea (Delav. Ex } \\
\text { Franch.) Finet et } \\
\text { Gagnep. }\end{array}$ & $\begin{array}{l}\text { II } \\
\text { EN }\end{array}$ & $\sqrt{ }$ & Pastures & $(1),(2)$ \\
\hline $\begin{array}{l}\text { Paris polyphylla Sm. } \\
\text { var. yunnanensis } \\
\text { (Franch) H. M. }\end{array}$ & II VU & $\sqrt{ }$ & $\begin{array}{l}\text { Needle-leaved and Broad- } \\
\text { leaved Forest }\end{array}$ & (1), (2) \\
\hline $\begin{array}{l}\text { Polygala tenuifolia } \\
\text { Willd. }\end{array}$ & III EN & & $\begin{array}{l}\text { Alt. } 2600-2650 \mathrm{~m} \text { secondary } \\
\text { Conifer Forest }\end{array}$ & $(4)$ \\
\hline
\end{tabular}

${ }^{23}$ Sources: Yuan et al. 2003; Zhang and Zheng 2000. 
Table 5 (cont.)

\begin{tabular}{|c|c|c|c|c|}
\hline Botanical Name & $\begin{array}{l}\text { Protection } \\
\text { Category }\end{array}$ & Endemism & Habitat & Source \\
\hline $\begin{array}{l}\text { Psammosilene } \\
\text { tunicoides W. C. Wu } \\
\text { et C. Y. Wu }\end{array}$ & II EN & $\sqrt{ }$ & Coniferous Forest & (2) \\
\hline $\begin{array}{l}\text { Saussurea involucrata } \\
\text { Kar. et Kir }\end{array}$ & III VU & $\sqrt{ }$ & $\begin{array}{l}\text { Alpine Weathering Gravel } \\
\text { Sparse Meadow }\end{array}$ & (4) \\
\hline Scutellaria baicalensis & III VU & - & Alpine Meadow & (4) \\
\hline $\begin{array}{l}\text { Skapanthus oreophilus } \\
\text { var. Elongatus (H.-M.) } \\
\text { Wu et Li }\end{array}$ & $\begin{array}{l}\text { II } \\
\text { EN }\end{array}$ & - & Pastures & (2) \\
\hline $\begin{array}{l}\text { Taxus wallichiana } \\
\text { Zucc. }\end{array}$ & I EN & $\sqrt{ }$ & $\begin{array}{l}\text { Alt. } 2000-3300 \mathrm{~m}, \text { Needle- } \\
\text { leaved and Broad-leaved } \\
\text { Forest }\end{array}$ & $(1),(2)$ \\
\hline $\begin{array}{l}\text { Torreya yunnanensis } \\
\text { Cheng et L. K. Fu }\end{array}$ & $\begin{array}{l}\text { II } \\
\text { EN }\end{array}$ & $\sqrt{ }$ & $\begin{array}{l}\text { Alt. } 2000-3200 \mathrm{~m} \text {, Conifer } \\
\text { and Broad-leaved Forest }\end{array}$ & $(1),(2)$ \\
\hline $\begin{array}{l}\text { Trillium tschonoskii } \\
\text { Maxim. }\end{array}$ & $\begin{array}{l}\text { III } \\
\text { VU }\end{array}$ & - & Coniferous Forest & (2) \\
\hline $\begin{array}{l}\text { Tricholoma matsutake } \\
\text { (Ito et Imai) Sing. }\end{array}$ & $\begin{array}{l}\text { II } \\
\text { VU }\end{array}$ & - & $\begin{array}{l}\text { Alt. } 1600-3200 \mathrm{~m} \text {, } \\
\text { Coniferous forest \& Broad } \\
\text { leaved forest }\end{array}$ & $(1),(2)$ \\
\hline
\end{tabular}

Key: EN=Endangered, $\mathrm{VU}=$ Vulnerable

\section{Conclusion}

The use of plants as medicines represents by far the biggest utilization of biodiversity globally in terms of number of species $(50,000-70,000),{ }^{24}$ representing around $20 \%$ of the world's flora. Contributions of medicinal plants in the Chinese Himalayan Region to the primary health care of people and economic growth at local and national levels are equally important. From a local community perspective, the conservation of medicinal plants is about maintaining or enhancing valued resources. Whether these resources are obtained from wild or cultivated plants can be of secondary concern.

\footnotetext{
${ }^{24}$ Schippmann and Leannan 2006.
} 
Medicinal plants are one of the most important kinds of biological resources in China, contributing greatly to the livelihoods of the Chinese people and to the national economy. However, the biological resource base of China and its habitats have been drastically changed in the past half-century. Degradation of biological resources and alteration of habitat of ecosystems have been the major concern among the public/civil society and the government. With the rapid economic development of China over the last twenty years (average annual GDP growth rate at 9\%), global climate change, economic globalisation, and regionalisation of development cooperation in the twenty-first century, the sustainable management of biodiversity resource and conservation of biodiversity in China, particularly in the Chinese Himalayan Region, is seen as a major challenge to the government and all people of China.

\section{Acknowledgements}

We wish to thank the International Association of the Study of Traditional Asian Medicine (IASTAM) and the organisers of the Seventh International Congress on Traditional Asian Medicine (ICTAM VII) for inviting Pei and sponsoring participation in the conference held 7-11 September 2009, in Thimphu, Bhutan. We wish also to thank Dr Sienna Craig and Dr Denise M. Glover who coordinated Pei's participation.

\section{References}

Chinese Corporation of Traditional and Herbal Medicine 1994, Outline of Chinese Medicinal Resources, Beijing: Science Press. [中国药材公司, 1994. 中国中药资源志要. 北京, 科学出版社.]

Duan, X. H., 2003, 'Investigation of present status of grassland in Hoh Xil National Natural Reserve', Pratacultural Science 20, 11: 11-14. [段秀华, 2003. 可可西里国家级自然保护区 草地现状调查. 草业科学, 20 (11): 11-14.]

Hamilton, A. 2004. 'Medicinal plants, conservation and livelihood', Biodiversity and Conservation 13: 1477-517.

Hong, D. and Z. Li 1995, 'Biodiversity and its conservation and management in the HinduKush-Himalayan Region of China', in Pei, S. (ed.), Banking on biodiversity: report on the regional consultation on biodiversity assessment in the Hindu Kush-Himalayas. December 19-20,1995, Kathmandu, Nepal, 131-79.

Huang, L. 2006, 'Hoh Xil is facing threatens from outside', Grand Garden of Science 6: 49-50. [黄丽, 2006. 可可西里面临 “五毒俱全” 威胁. 科学大观园, (6):49-50.]

ICIMOD 1994, International Symposium on Mountain Environment and Development 10th Anniversary, Part B-D. Natural Resources Management in a Mountain Environment, 1-78.

Inglis, J. 1994, 'Introduction', Nature \& Resources 30: 3-4. 
Institute of Botany 1992, The Red Book of China, Beijing: Science Press. [中国科学院植物研究 所, 1992, 中国植物红皮书. 北京, 科学出版社.]

Pei, S. J. 1987, 'Medicinal plants in tropical areas of China'. Proceedings of Symposium 5-35, the 14th International Botanical Congress, Berlin. Wageningen, Netherlands: PUDOC.

- 1998, 'Biodiversity Conservation in the Mountain Development of Hindu KushHimalayas in Frontiers in Biology', in C. H. Chon and K. T. Shao (eds) The Challenge of Biodiversity, Biotechnology and Sustainable Agriculture. Taipei: Academia Sinica.

_ 2002, 'Bio-cultural diversity and development of West China', Journal of Graduate School of Chinese Academy of Science 19, 2: 107-15.

Schippmann, U. and D. J. Leannan 2006, 'Cultivation and Wild Collection of Medicinal and Aromatic Plants under Sustainability Aspects', in B. J. Bogers et al. (eds), Medicinal and Aromatic Plants, Dordreeht: Springer.

SEPA 1998, Status Report on Chinese National Biodiversity, Beijing: Environmental Science Press.

Wang, Y. H., S. J. Pei, and J. C. Xu 2002. 'Sustainable in an agreement of Medicinal Plant Resources in China: Literature Review and implications', Resource Science 24, 4: 81-8. [王雨华, 裴盛基, 许建初, 2002. 中国药用植物资源可持续管理的实践与建议. 资源科 学, 24 (4): 81-88.]

Wu, C. Y. 1979, 'The regionalization of Chinese Flora', in C. Y. Wu (ed.), The Vegetation of China, Acta Botanica Yunnanica I, 1: 1-22. [吴征镒, 1979. 论中国植物区系的分区问题. 云南植物研究 I (1): 1-22.]

Yang, J. 1988, Tibetan Medicines in Diqing, Kunming: Yunnan Nationality Publishing House.[ 杨竞生, 1988. 迪庆藏药. 云南民族出版社, 昆明.]

Yuan, C. Q. et al., 2003, 'Conservation of Endangered Medicinal Plants in China', in Zheng (ed.) Resource Science of Medicinal Materials, Shanghai: Secondary Military University Press. [袁昌齐等, 2003. 中国濒危药用植物的保护, 郑汉臣 (主编), 中药资源学, 上海, 第二军医大学出版社.]

Zhang, E. D. and H. C. Zheng 2000, Conservation of Endangered Medicinal Wild Resources in China, Shanghai: The Second Military Medical University Press. [张恩迪, 郑汉臣 (主编), 2000. 中国濒危野生药用动植物资源的保护. 第二军医大学出版社, 上海.]

Zhao, Y. H. 2008, 'The most beautiful wetland in China-Zoige Pastures, is quickly disappearing', Ecological Economy 1: 16-21. [赵亚辉, 2008. 中国最美湿地若尔盖草原正在加速消 失. 生态经济, 1: 16-21.]

Zheng, H. C. 2003, Resource Science of Medicinal Materials, Shanghai: The Second Military Medical University Press. [郑汉臣, 2003. 中药资源学. 第二军医大学出版社, 上海.]

Zhou, X. J., H. F. X., and Q. S. Shun 2007, Resource Science of Chinese Medicinal Materials: Protection and sustainable use of Chinese medicinal material resources, TRAFFIC East Asia. Shanghai: Shanghai Science and Technology Documentation House. [周秀佳, 徐宏发, 顺庆生, 2007. 中药资源学一一药资源的保护与可持续利用, 上海科学出版社.] 